\title{
Screening of Asteraceae (Compositae) Plant Extracts for Larvicidal Activity against Aedes fluviatilis (Diptera: Culicidae)
}

\author{
Maria E Macêdo, Rotraut AGB Consoli, Telma SM Grandi**, Antônio MG dos \\ Anjos**, Alaíde B de Oliveira***, Nelymar M Mendes*, Rogério O Queiróz*, \\ Carlos L Zani*/+
}

Laboratório de Biologia e Sistemática de Culicídeos *Laboratório de Química de Produtos Naturais, Centro de Pesquisas René Rachou-FIOCRUZ, Caixa Postal 1743, 30190-002 Belo Horizonte, MG, Brasil *** Departamento de Botânica, ICB, UFMG, Belo Horizonte, MG, Brasil ${ }^{* * *}$ Faculdade de Farmácia, UFMG,

Belo Horizonte, MG, Brasil

Ethanol extracts of 83 plants species belonging to the Asteraceae (Compositae) family, collected in the State of Minas Gerais, Brazil, were tested for larvicidal activity against the mosquito Aedes fluviatilis - Diptera: Culicidae). The extract from Tagetes minuta was the most active with a $L C_{90}$ of $1.5 \mathrm{mg} / \mathrm{l}$ and $L C_{50}$ of $1.0 \mathrm{mg} / \mathrm{l}$. This plant has been the object of several studies by other groups and its active components have already been identified as thiophene derivatives, a class of compounds present in many Asteraceae species. The extract of Eclipta paniculata was also significantly active, with a $L C_{90}$ of 17.2 $\mathrm{mg} / \mathrm{l}$ and $L_{50}$ of $3.3 \mathrm{mg} / \mathrm{l}$ and no previous studies on its larvicidal activity or chemical composition could be found in the literature. Extracts of Achryrocline satureoides, Gnaphalium spicatum, Senecio brasiliensis, Trixis vauthieri, Tagetes patula and Vernonia ammophila were less active, killing more than $50 \%$ of the larvae only at the higher dose tested $(100 \mathrm{mg} / \mathrm{l})$.

Key words: mosquitoes - larvicidal - Aedes fluviatilis - Asteraceae - plant extracts

The selective pressure of conventional insecticides is enhancing resistance of mosquito populations at an alarming rate (Brown 1986), increasing the demand for new products that are environmentally safe, target-specific and degradable.

Co-evolution has equipped plants with a plethora of chemical defenses against insect predators. Aware of this effect, mankind has used plant parts or extracts to control insects since ancient times. Plant derived products have received increased attention from scientists and more than 2000 plant species are already known to have insecticide properties (Balandrin 1985, Rawls 1986, Sukamar et al. 1991). Natural insecticides such as pyrethrum, rotenone and nicotine, among others, have been extensively used until recently for insect control (Balandrin 1985). Limonoids such as azadirachtin and gedunin, present in species from the Meliaceae and Rutaceae are recognized for their toxic effects on insects and are used in several in-

Supported by CNPq/FIOCRUZ

${ }^{+}$Corresponding author. Fax: $+55-31-295.3115$. E-mail: zani@dcc001.cict.fiocruz.br

Received 16 August 1996

Accepted 21 March 1997 secticide formulations in many parts of the world (Dua et al. 1995, Nagpal et al. 1996). Recently, the discovery of insecticide activity of phototoxins present in Asteraceae species has stimulated the interest in this plant family as part of the search for new plant derived insecticides (Rawls 1986).

In Brazil, the resurgence of several mosquito transmitted diseases such as malaria, dengue and yellow fever, together with the appearance of insect resistance to conventional insecticides, stresses the necessity for the search for new insecticides. Aiming for the discovery of cost effective alternatives for the control of disease vector insects, we decided to evaluate the toxicity of crude ethanol extracts of 83 Asteraceae species from our local flora against the larvae of Aedes (Ochlerotatus) fluviatilis (Lutz, 1904). This mosquito shares many biological characteristics with Ae. aegypti, the vector of yellow fever, and has been shown to be an useful model in biological studies of experimental infections and insecticide susceptibility tests (Consoli \& Williams 1978, 1981, Camargo et al. 1983).

\section{MATERIALS AND METHODS}

Plant collection - The plants (Table I) were collected in Belo Horizonte and its vicinities, in the State of Minas Gerais, Brazil. After botanical 
TABLE I

Asteraceae plant species collected for testing against 4th instar larvae of Aedes (Ochlerotatus) fluviatilis (Lutz, 1904)

\begin{tabular}{|c|c|c|c|c|}
\hline Entry & Plants & Common name & Habitat $^{a}$ & $\mathrm{BHCB}^{b}$ \\
\hline 1. & Acanthospermum australe (Loef.) Kunt. & carrapicho de carneiro & $\mathrm{W}$ & 19056 \\
\hline 2. & Achyrocline alata DC. & macela & $\mathrm{S}$ & 19017 \\
\hline 3. & Achyrocline satureiodes (Lam.) DC. & macela do campo & $\mathrm{S}$ & 19067 \\
\hline 4. & Actinoseris angustifolia (Gard) Cabr. & - & $\mathrm{S}$ & 19086 \\
\hline 5. & Ageratum conyzoides $\mathrm{L}$. & catinga de bode & $\mathrm{C}$ & 19031 \\
\hline 6. & Alomia myriadenia Baker & - & $\mathrm{S}$ & 19013 \\
\hline 7. & Aspilia jolyana G.M. Barroso & - & $\mathrm{S}$ & 19200 \\
\hline 8. & Aspilia serrulata Baker & - & $\mathrm{S}$ & 19019 \\
\hline 9. & Baccharis dracunculifolia DC. & - & $\mathrm{S}$ & 19048 \\
\hline 10. & Baccharis helichrysoides DC. & - & $\mathrm{C}$ & 19101 \\
\hline 11. & Baccharis platypoda DC. & - & $\mathrm{S}$ & 19063 \\
\hline 12. & Baccharis serrulata (Lam.)Pers. & suncho & $\mathrm{S}$ & 19054 \\
\hline 13. & Baccharis trimera (L.) DC. & carqueja & $\mathrm{S}$ & 19077 \\
\hline 14. & Baccharis trinervis Pers. & - & W & 19062 \\
\hline 15. & Bidens gardneri Baker & - & $\mathrm{C}$ & 19028 \\
\hline 16. & Bidens pilosa $\mathrm{L}$. & picão & $\mathrm{S}$ & 19014 \\
\hline 17. & Bidens rubifolius $\mathrm{HBK}$ & - & $\mathrm{C}$ & 19023 \\
\hline 18. & Blainsvillea biaristata DC. & - & $\mathrm{W}$ & 19052 \\
\hline 19. & Centratherum punctatum Cass. & - & $\mathrm{W}$ & 19045 \\
\hline 20. & Chaptalia nutans (L.) Polak & fumo do mato & W & 19089 \\
\hline 21. & Cosmus sulphureus Cav. & picão grande & $\mathrm{W}$ & 19046 \\
\hline 22. & Dasyphyllum macrocephala Baker & - & $\mathrm{S}$ & 19076 \\
\hline 23. & Eclipta paniculata Hassk. & - & $\mathrm{W}$ & 19037 \\
\hline 24. & Elephantopus mollis $\mathrm{HBK}$ & erva colégio & $\mathrm{C}$ & 19032 \\
\hline 25. & Emilia sonchifolia DC. & pincel de estudante & $\mathrm{W}$ & 19034 \\
\hline 26. & Eremanthus glomerulatus (DC.) Less & - & $\mathrm{S}$ & 19073 \\
\hline 27. & Eremanthus sphaerocephalus (DC.) Baker & chapéu de couro & $\mathrm{S}$ & 19058 \\
\hline 28. & Erigeron bonariensis L. & erva lanceta & $\mathrm{W}$ & 19090 \\
\hline 29. & Erigeron canadensis L. & - & $\mathrm{W}$ & 19039 \\
\hline 30. & Eupatorium amphidictyum DC. & - & $\mathrm{S}$ & 19065 \\
\hline 31. & Eupatorium bupleurifolium DC. & guaco & $\mathrm{S}$ & 19051 \\
\hline 32. & Eupatorium aff. capilare DC. & - & $\mathrm{C}$ & 19029 \\
\hline 33. & Eupatorium halimifolium DC. & - & $\mathrm{S}$ & 19102 \\
\hline 34. & Eupatorium klenioides HKB & - & $\mathrm{C}$ & 19024 \\
\hline 35. & Eupatorium laevigatum Lam. & cambaré & $\mathrm{S}$ & 19050 \\
\hline 36. & Eupatorium squalidum DC & erva São João & $\mathrm{C}$ & 19022 \\
\hline 37. & Galinsoga parviflora Cav. & picão branco & $\mathrm{S}$ & 19015 \\
\hline 38. & Gnaphalium spicatum Hook & macela & $\mathrm{W}$ & 19088 \\
\hline 39. & Gochnatia polymorpha (Less.) Cabr. & cambará do mato & $\mathrm{S}$ & 19078 \\
\hline 40. & Hypochaeris brasiliensis Griseb & chicória do campo & $\mathrm{W}$ & 19092 \\
\hline 41. & Jaegeria hirta (Lag.) Less & jeguéria & $\mathrm{W}$ & 19040 \\
\hline 42. & Jungia floribunda Less & arnica & $\mathrm{W}$ & 19057 \\
\hline 43. & Lychnophora pinaster & - & $\mathrm{S}$ & 19020 \\
\hline 44. & Lychnophora pseudovillosissima Semir \& L.F. & - & $\mathrm{S}$ & 19103 \\
\hline 45. & Mikania aff. premnifolia Gardn. & - & $\mathrm{S}$ & 19096 \\
\hline 46. & Mikania cordifolia (L.F.) Wild & guaco & $\mathrm{S}$ & 19047 \\
\hline 47. & Mikania lutzelburghii Mattf. & - & $\mathrm{S}$ & 19061 \\
\hline 48. & Mikania obtusata DC. & - & $\mathrm{S}$ & 19069 \\
\hline 49. & Mikania sessilifolia DC. & cundurango & $\mathrm{S}$ & 19060 \\
\hline 50. & Piptocarpa rotundifolia Baker & paratudo & $\mathrm{C}$ & 19087 \\
\hline 51. & Pluchea quitoc L. & quitoco & $\mathrm{W}$ & 19036 \\
\hline 52. & Porophillum ruderale (Jacq. ) Cass. & couve cravinho & $\mathrm{C}$ & 19030 \\
\hline 53. & Pseudoginonoxis pohlii (Sch.-Bip.) L.F. & - & $\mathrm{S}$ & 19098 \\
\hline 54. & Pterocaulon alopecureoides (Lam.) DC. & barbasco & $\mathrm{C}$ & 19025 \\
\hline 55. & Senecio brasiliensis Less & flor das almas & $\mathrm{C}$ & 16377 \\
\hline 56. & Senecio confusus Britten & - & $\mathrm{W}$ & 19035 \\
\hline 57. & Siegesbeckia orientalis L. & - & $\mathrm{W}$ & 19091 \\
\hline
\end{tabular}




\begin{tabular}{|c|c|c|c|c|}
\hline Entry & Plants & Common name & Habitat $^{a}$ & $\mathrm{BHCB}^{l}$ \\
\hline 58. & Sonchus oleraceus L. & serralha lisa & $\mathrm{W}$ & 19038 \\
\hline 59. & Spilanthes paniculata Well ex. DC. & - & $\mathrm{W}$ & 19196 \\
\hline 60. & Stenocline chionaea DC. & - & $\mathrm{S}$ & 19064 \\
\hline 61. & Symphyopappus polystachyus Baker & & $\mathrm{C}$ & 19059 \\
\hline 62. & Symphyopappus reticulatus Baker & - & $\mathrm{S}$ & 19100 \\
\hline 63. & Tagetes minuta $\mathrm{L}$ & coarí bravo & $\mathrm{W}$ & 19055 \\
\hline 64. & Tagetes patula $\mathrm{L}$. & cravo de defunto & $\mathrm{W}$ & 00373 \\
\hline 65. & Taraxacum officinale (With.) Wiggers & dente de leão & $\mathrm{W}$ & 19070 \\
\hline 66. & Tithonia rotundifolia Baker & - & $\mathrm{W}$ & 19026 \\
\hline 67. & Trixis vauthieri DC. & celidônia & $\mathrm{S}$ & 19072 \\
\hline 68. & Vanillosmopsis erithropappa Sch.-Bip. & cambará & $\mathrm{S}$ & 19082 \\
\hline 69. & Verbesina clausseni Sch.-Bip. & cravo do campo & $\mathrm{S}$ & 19016 \\
\hline 70. & Vernonia ammophila Gardn. & - & $\mathrm{C}$ & 19027 \\
\hline 71. & Vernonia condensata Baker & - & $\mathrm{W}$ & 19081 \\
\hline 72. & Vernonia crotonoides (DC.) Sch.-Bip. & cambará & $\mathrm{S}$ & 19021 \\
\hline 73. & Vernonia ferruginea Less. & assa-peixe do Pará & $\mathrm{C}$ & 19083 \\
\hline 74. & Vernonia grandiflora Less. & saudades do campo & $\mathrm{W}$ & 19195 \\
\hline 75. & Vernonia herbaceae (Vell.) Rusby & - & $\mathrm{W}$ & 19041 \\
\hline 76. & Vernonia linearis Spreng & - & $\mathrm{S}$ & 19066 \\
\hline 77. & Vernonia pedunculata DC. & - & $\mathrm{S}$ & 19084 \\
\hline 78. & Vernonia polyanthes (Spreng.) Less & cambará guaçu & $\mathrm{W}$ & 19080 \\
\hline 79. & Vernonia remotiflora Rich. & - & $\mathrm{W}$ & 19053 \\
\hline 80. & Vernonia varroniaefolia DC. & - & $\mathrm{W}$ & 19042 \\
\hline 81. & Viguiera ovatifolia Baker & - & $\mathrm{S}$ & 19074 \\
\hline 82. & Wedelia paludosa DC. & margaridão & $\mathrm{W}$ & 19033 \\
\hline 83. & Wulfia baccata (L.F.) Kuntz & - & $\mathrm{W}$ & 19093 \\
\hline
\end{tabular}

$a$ : C: Cerrado (savanna); $\mathrm{S}$ : stony areas; $\mathrm{W}$ : weeds. $b$ : voucher specimen code at BHCB Herbarium, Departamento de Botânica, Universidade Federal de Minas Gerais, Brasil.

identification, voucher specimens were deposited in the BHCB Herbarium at the Department of Botany, Federal University of Minas Gerais.

Extracts preparation - The aerial parts of the plants were dried in the shade, ground in a knife mill or in a homogenizer and extracted twice (24 hr) with ethanol (95\%) at room temperature. The solvent was removed by rotary evaporation under reduced pressure at temperature below $45^{\circ} \mathrm{C}$. The resulting crude extracts were stored in a freezer at $-20^{\circ} \mathrm{C}$ until assayed. Immediately before running the bioassay, sufficient amounts of extract were transferred to a vial and the residual solvent removed under high vacuum for at least $24 \mathrm{hr}$.

Bioassay - Stock solutions of each extract were prepared at $1000 \mathrm{mg} / \mathrm{l}$ by sonicating them in a ultrasound bath $(45 \mathrm{kHz}, 100 \mathrm{~W})$ for $5-10 \mathrm{~min}$. Test solutions of 100,10 and $1 \mathrm{mg} / \mathrm{l}$ were then prepared by diluting the stock solution in tap water. The extracts were tested against young fourth instar Ae.(Ochlerotatus) fluviatilis (Lutz, 1904) larvae from a colony maintained at the Centro de Pesquisas René Rachou (Consoli \& Lourenço-deOliveira 1994). Each dilution was placed in sterile glass dishes ( $9 \mathrm{~cm}$ diam. $/ 150 \mathrm{ml}$ capacity) and 30 larvae were added. After $24 \mathrm{hr}$ contact at room tem- perature, the number of dead larvae in each dish was counted. The larvae were considered dead if they were immobile and unable to reach the water surface. Previous experiments showed no significant differences in mortality when the assay was extended to $48 \mathrm{hr}$ (Consoli et al. 1988). The ambient temperature during all experiments ranged between $23-28^{\circ} \mathrm{C}$. Control experiments without extract were run in parallel and the mortality was always bellow $4.5 \%$. All experiments were run in triplicate.

Statistical evaluation - Mortality means were compared using Duncan's Test (Edwards 1960) at the alpha significance level of $0.05 ; \mathrm{LC}_{50}$ and $\mathrm{LC}_{90}$ were calculated for the most active extracts using probit analysis (Armitage \& Berry 1987).

\section{RESULTS AND DISCUSSION}

Eighty-three species, belonging to 48 genera of the Asteraceae family were collected for this survey. Table I lists all plants in alphabetical order and includes their habitats, BHCB herbarium codes and common name when available (Corrêa 1984). The genera Baccharis, Eupatorium, Mikania and Vernonia were the best represented, with at least five species each. 
Table II summarizes the results of the bioassays for those species that promoted statistically significant mortality, using Duncan's significance test (Edwards 1960), for at least one concentration when compared to the control. Larvicidal activities higher than $50 \%$ at any tested concentration were highlighted.

The crude extract from the aerial parts of $T$. minuta (Table II, entry 22) displayed an $\mathrm{LC}_{90}$ and an $\mathrm{LC}_{50}$ of 1.5 and $1.0 \mathrm{mg} / \mathrm{l}$, respectively, making it the most active of all extracts tested. 5-Eocimenone was initially described as the active component of Tagetes minuta (Maradufu et al. 1978) but Green et al. (1991) suggested that further compounds, not identified by them, were also responsible for the observed toxicity towards mosquito larvae. More recently, four thiophene derivatives were identified from a larvicidal floral extract fraction of this plant (Perich et al. 1995). This fraction displayed an $\mathrm{LC}_{50}$ of 3.9 against Ae. aegypti and Anopheles stephensi 3 rd instar larvae, i. e., four times less potent than the crude extract tested here.

T. patula extract (Table II, entry 23) which is also known to contain thiophene derivatives (Bicchi et al. 1992) was, on the other hand, much less active than T. minuta, a result that is in agreement with other published works (Green et al. 1991, Wells et al. 1993, Perich et al. 1994).

The extract of Eclipta paniculata was the second most active of the 83 tested in this screening. It promoted the death of $83 \%$ of the larvae at 10 $\mathrm{mg} / \mathrm{l}$ and presented $\mathrm{LC}_{90}$ and $\mathrm{LC}_{50}$ values of 17.2 and $3.3 \mathrm{mg} / \mathrm{l}$, respectively. No studies describing its insecticide activity or chemical fractionation has been found in the literature. However, considering the chemistry of the genus Eclipta (Singh 1988), it is conceivable that thiophene and polyacetylene derivatives are also present in E. paniculata and could account for its larvicidal properties. A bioassay-guided fractionation of E. paniculata extract will be necessary to confirm this hypothesis.

The extracts of Achryrocline satureoides,

TABLE II

Extracts that caused significant lethality of Aedes fluviatilis fourth instar larvae ${ }^{a}$

\begin{tabular}{|c|c|c|c|c|}
\hline \multirow{3}{*}{ Entry } & \multirow{3}{*}{ Plants } & \multicolumn{3}{|c|}{$\%$ mortality } \\
\hline & & \multicolumn{3}{|c|}{ concentration (mg/l) } \\
\hline & & 100 & 10 & 1 \\
\hline 1. & Achyrocline alata & 14.4 & 2.2 & 1.1 \\
\hline 2. & Achyrocline satureoides & 52.2 & 4.4 & 5.6 \\
\hline 3. & Ageratum conyzoides & 11.1 & 1.1 & 2.2 \\
\hline 4. & Alomia myriadenia & 20.0 & 4.4 & 1.1 \\
\hline 5. & Aspilia serrulata & 12.2 & 14.2 & 2.2 \\
\hline 6. & Bidens pilosa & 12.2 & 2.2 & - \\
\hline 7. & Chaptalia nutans & 34.4 & - & 2.2 \\
\hline 8. & Eclipta paniculata & 98.8 & 83.3 & 17.8 \\
\hline 9. & Emilia sonchifolia & 44.4 & 18.9 & 12.2 \\
\hline 10. & Eremanthus glomerulatus & 13.3 & 7.8 & 6.7 \\
\hline 11. & Erigeron bonariensis & 34.4 & 2.2 & - \\
\hline 12. & Eupatorium aff. capilare & 11.1 & 5.6 & 2.2 \\
\hline 13. & Gnaphalium spicatum & 76.7 & 2.2 & 1.1 \\
\hline 14. & Jaegeria hirta & 32.2 & 4.4 & 6.7 \\
\hline 15. & Jungia floribunda & 32.2 & - & - \\
\hline 16. & Lychnophora pinaster & 48.9 & 1.1 & 2.2 \\
\hline 17. & Mikania sessifolia & 25.6 & 3.3 & - \\
\hline 18. & Pluchea quitoc & 40.0 & 1.1 & 1.1 \\
\hline 19. & Porophillum ruderale & 13.3 & 5.6 & 1.1 \\
\hline 20. & Pterocaulon alopecureoides & 10.0 & 3.3 & 2.2 \\
\hline 21. & Senecio brasiliensis & 54.4 & 2.2 & - \\
\hline 22. & Tagetes minuta & 100.0 & 100.0 & 48.9 \\
\hline 23. & Tagetes patula & 65.6 & 25.6 & 23.3 \\
\hline 24. & Tithonia rotundifolia & 20.0 & 8.9 & - \\
\hline 25. & Trixis vauthieri & 56.6 & 13.3 & 2.2 \\
\hline 26. & Verbesina clausseni & 26.7 & 5.6 & 2.2 \\
\hline 27. & Vernonia ammophila & 93.3 & 2.2 & 1.1 \\
\hline
\end{tabular}

$a$ : experiments run in triplicate, using 90 larvae for each concentration. The mortality in the control without extract was always bellow $4.4 \%$ 
Gnaphalium spicatum, Senecio brasiliensis, Trixis vauthieri and Vernonia ammophila were much less active than those discussed above. Concentrations of $100 \mathrm{mg} / \mathrm{l}$ for each extract were necessary to kill more than $50 \%$ of the larvae (Table II). The extract of $V$. ammophila, for example, showed $\mathrm{LC}_{90}$ and $\mathrm{LC}_{50}$ values of 87.8 and $40 \mathrm{mg} / \mathrm{l}$, respectively. To the best of our knowledge this is the first time the larvicidal activity of these species has been described. The extract of $T$. vauthieri has already been the object of phytochemical studies (Bohlmann et al. 1981, Ribeiro et al. 1994) and has been shown to contain 7-methoxyaromadendrin, a larvicidal flavonoid (Echeverry et al. 1992) that could account for its activity. In addition to these studies, a bioassay-guided chemical fractionation protocol should be conducted in order to identify further larvicidal components in this extract.

Except for the extracts discussed above, all others listed in Table II were unable to kill more than $50 \%$ of the larvae at the highest concentration tested $(100 \mathrm{mg} / \mathrm{l})$ and were considered weakly active. Concerning these species, comparison of our results to those found in the literature yielded the following observations: a) the extract of Ageratum conyzoides, reported to be larvicidal in a previous work (Sujatha et al. 1988), was devoid of activity in the present trial; b) the genera Bidens, Mikania and Verbesina, known to contain species with pronounced insecticide activity (Heal et al. 1950, Consoli et al. 1988), afforded no larvicidal extract under our experimental conditions; c) extracts of A. australe, A. conyzoides, B. pilosa, E. bonariensis, J. floribunda, P. ruderale, $P$. alupecuroides and V. claussenii showed no effect over Ae. fluviatilis larvae in this study but have, according to previous works (Macêdo 1995), interfered with oviposition behavior in this species suggesting that different components in the extracts are responsible for these effects; d) while Heal et al. (1950) described the activity of five Baccharis species against Ae. aegypti and An. quadrimaculatus larvae in his survey (Heal et al. 1950), none of the six Baccharis species tested here were larvicidal. These inconsistencies in activities may be attributable to seasonal fluctuations in the biosynthesis of the active components, differences in extraction methods, bioassay protocols or difficulties in species authentication (Farnsworth 1966).

In conclusion, from this screening several larvicidal extracts were detected among local Asteraceae species, some of them already described by other research groups. T. minuta was the most active and thiophene derivatives were identified as its larvicidal components (Perich et al. 1995). The larvicidal flavonoid 7-metho-xyaromadendrin is present in T. vauthieri extracts (Bohlmann et al. 1981, Ribeiro et al. 1994) and could account, at least in part, for its larvicidal activity. Finally, the extract of E. paniculata showed strong activity and, as it has not yet been subjected to any phytochemical investigation, it is a good candidate for a bioassay-guided fractionation to identify its larvicidal constituents. It is conceivable that its active components are also thiophene or polyacetylene derivatives, compounds very common in the genus Eclipta. Studies to confirm this hypothesis are underway.

\section{ACKNOWLEDGMENTS}

To Prof. Júlio A Lombardi, Curator of the Dept. of Botânica Herbarium, ICB/UFMG, for his kind help.

\section{REFERENCES}

Armitage P, Berry G 1987. Statistical Methods in Medical Research. 2nd ed. Blackwell Scientific Publications. Oxford. $559 \mathrm{pp}$.

Balandrin MF 1985. Natural Plant Chemicals: Sources of Industrial and Medicinal Materials. Science 228: 1154-1160.

Bicchi C, Frattini C, Pellegrino G, Raverdino V, Tsoupras G 1992. Determination of sulphurated compounds in Tagetes patula cv. nana essential oil by gas chromatography with mass spectroscopic, fourier transform infrared and atomic emission spectrometric detection. J Chromatogr 1/2: 305-313.

Bohlmann F, Suwita A, Jakupovic J, King RM, Robinson $\mathrm{H}$ 1981. Trixingolides and germacrene derivatives from Trixis species. Phytochemistry 20: 1649-1655.

Brown AWA 1986. Insecticide resistance in mosquitoes: a pragmatic review. J Am Mosq Contr Ass 2: 123139.

Camargo MVT, Consoli RAGB, Williams P, Krettli AU 1983. Factors influencing the development of Plasmodium gallinaceum in Aedes fluviatilis. Mem Inst Oswaldo Cruz 78: 83-94.

Consoli RAGB, Lourenço-de-Oliveira R 1994. Principais mosquitos de importância sanitária no Brasil. Editora FIOCRUZ, Rio de Janeiro, 225 pp.

Consoli RAGB, Williams P 1978. Laboratory observations on the bionomics of Aedes fluviatilis (Lutz) (Diptera: Culicidae). Bull Entomol Res 68: 123-136.

Consoli RAGB, Williams P 1981. Aspects of the biology of laboratory-reared female Aedes fluviatilis. Mosquito News 41: 30-36.

Consoli RAGB, Mendes NM, Pereira JP, Santos BS, Lamounier MA 1988. Influência de diversos derivados de vegetais na sobrevida das larvas de Aedes fluviatilis (Lutz) (Diptera: Culicidae) em laboratório. Mem Inst Oswaldo Cruz 83: 87-93.

Corrêa MP 1984. Dicionário das Plantas Úteis do Brasil e das Exóticas Cultivadas. Ministério da Agricultura - IBDF, Rio de Janeiro, vol. I-VI.

Dua VK, Nagpal BN, Sharma VP 1995. Repellent action of neem cream against mosquitoes. Indian $J$ Malariol 32: 47-53.

Echeverry F, Torres F, Cordona G, Lopez J, Quinones 
WGLH, Pelaes CA, Rojas M, Garcia F, Restrepo LM 1992. Larvicidal activity of 7methoxyaromadendrin against Culex sp. larvae. Rev Boliv Quim 11: 43-5.

Edwards AL 1960. Experimental design in psychology research: introduction to the analysis of variance. Rinehard \& Consc, New York, 363 pp.

Farnsworth NR 1966. Biological and phytochemical screening of plants. J Pharm Sci 55: 225-276.

Green MM, Singer JM, Sutherland DJ, Hibben CR 1991. Larvicidal activity of Tagetes minuta (Marigold) toward Aedes aegypti. J Amer Mosq Control Ass 7: 282-286.

Heal RE, Rogers EF, Wallace RT, Starnes O 1950. A survey of plants for insecticidal activity. Llodyia 13: 89-162.

Macêdo ME 1995. Influência de alguns derivados de vegetais da família Asteraceae sobre o comportamento de oviposição, eclosão larvária e efeito atrativo ou repelente exercido sobre os adultos de Aedes (Ochlerotatus) fluviatilis (Lutz, 1904). Thesis, ICB-Univ. Federal de Minas Gerais, $111 \mathrm{pp}$.

Maradufu AR, Lubega R, Dorn F 1978. Isolation of (5E) - Ocimenone, a mosquito larvicide from Tagetes minuta. Lloydia 41: 181-183.

Nagpal BN, Srivastava A, Sharma VP 1996. Control of mosquito breeding using scrapings trated with neem oil. Indian J Malariol 32: 64-69.

Perich MJ, Well SC, Bertsch WG, Tredway KE 1994.
Toxicity of extracts from three Tagetes against adults and larvae of yellow fever mosquito and Anopheles stephensi (Diptera: Culicidae). J Med Entomol 31: 833-837.

Perich MJ, Wells C, Bertsch W, Tredway KE 1995. Isolation of the insecticidal components of Tagetes minuta (Compositae) against mosquito larvae and adults. J Am Mosq Control Ass 11: 307-310.

Rawls RL 1986. Experts probe issues, chemistry of lightactivated pesticides. Chem Eng News Sep 22: 2124.

Ribeiro A, Santos LMST, Romanha AJ, Veloso DP, Zani CL 1994. Flavonoids from Trixis vauthieri D. C. (Asteraceae) extract active in vitro against trypomastigote forms of Tripanosoma cruzi. Mem Inst Oswaldo Cruz 89: 188.

Singh P 1988. Naturally-occurring thiophene derivatives from Eclipta species. Bioact Mol 7: 179-186.

Sujatha CH, Vasuki V, Mariappan T, Kalyanasundaran M, Das PK 1988. Evaluation of plant extracts for biological activity against mosquitoes. Int Pest Control 30: 122-124.

Sukamar K, Perich MJ, Boobar LR 1991. Botanical derivatives in mosquito control: a review. J Amer Mosq Control Ass 7: 210-237.

Wells C, Bertsch W, Perich M 1993. Insecticidal volatiles from the marigold plant (Genus Tagetes). Effect of species and sample manipulation. Chromatographia 35: 209-215. 